Año LI. urtea

$128-2019$

Uztaila-abendua Julio-diciembre

Sor 20

(ans

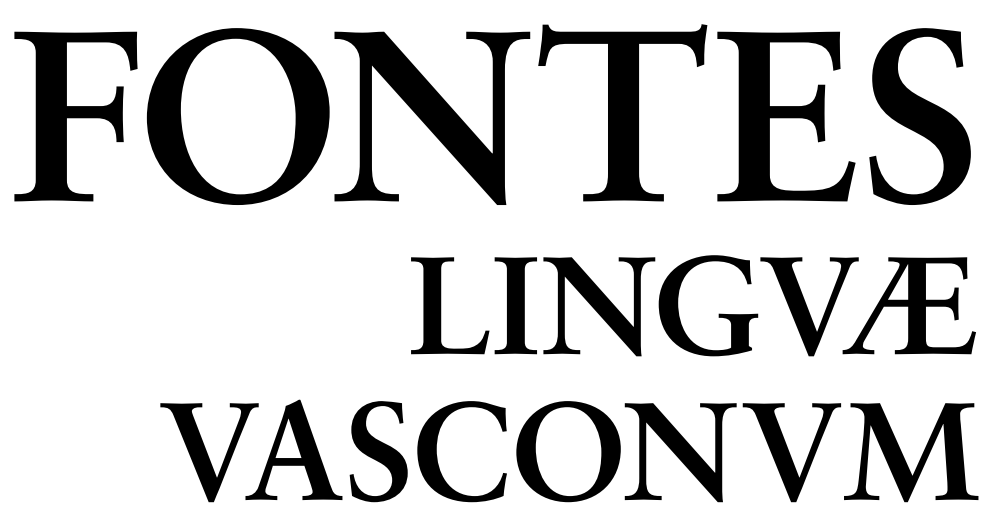

STVDIA ET DOCVMENTA

SEPARATA

\title{
Kode-aldaketaren tipologia euskal gazteen txatetan
}

Esther ZuLAIKA IJURKO

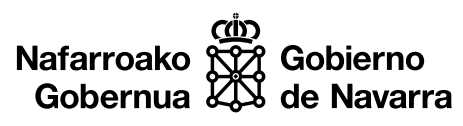

- 00 


\section{Kode-aldaketaren tipologia euskal gazteen txatetan}

Tipología del code-switching en las conversaciones de chat de los jóvenes vascos

A typology of code-switching in chat talks among Basque youth

Esther ZULAIKA IJURKO

Deustuko Unibertsitatea

esther.zulaika@deusto.es 


\section{LABURPENA}

Artikulu honetan gazte euskaldunek gizarte-sareetan ekoitzitako mezuen alderdi bat aztertuko dugu: euskara-gaztelania code-switching edo kode-aldaketa. Txatetako elkarrizketa idatziez baliatuta, alternantzien azterketak hiru mota utzi ditu agerian: perpaus barnekoa, perpausen artekoa eta enblematikoa. Gazteen komunikazio-gaitasunean sakontzeko urratsa dela uste dugu, bereziki gazteen lagunarteko hizkeran.

Gako hitzak: kode-aldaketa; euskara-gaztelania; gazte hizkera; gizarte sareak; komunikazio gaitasuna.

\section{RESUMEN}

El objetivo de este artículo es analizar la tipología del cambio de código o code-switching euskera-castellano en los discursos de los jóvenes vascos en las redes sociales. Las conversaciones escritas de los chats mostrarán tres tipos de cambio: intraoracional, interoracional y emblemático. Creemos que el análisis supone un paso más para profundizar en la competencia comunicativa de los jóvenes, en especial en el lenguaje escrito coloquial.

Palabras clave: cambio de código; euskera-castellano; lenguaje juvenil; redes sociales; competencia comunicativa.

\section{ABSTRACT}

The aim of this paper is to examine the typology of Basque-Spanish code-switching in social network talks among Basque youth. Written chat talks show three types of code-switching: intrasentential, intersentential and emblematic switching. We believe that the analysis is a further step to gain insight into youth's communication skills, especially in colloquial written language.

Keywords: Code-switching; Basque-Spanish; youth language; social networks; communication skills. 
1. SARrera. 2. Hurbilbide teorikoA. 3. Kode-Aldaketa gaZte EusKaldunen ELKARRIZKETA MINTZIDATZIETAN. 4. AZTERBIDEA ETA LAGINAREN EZAUGARRIAK. 5. EUSKARA-GAZTELANIA KA. INGURUNE SINTAKTIKOAREN ARABERAKO TIPOLOGIA. 5.1. Perpaus barneko KA. 5.2. Perpausen arteko KA. 5.3. KA enblematikoa. 6. ONDORIOAK. 7. ERREFERENTZIAK.

\section{SARRERA}

Artikulu hau euskal gazteen komunikazio gaitasunen ikerketaren ildoan kokatzen da; zehatz esanda, gizarte-sareen eremu informalean. Gazteek geroz eta gehiago jotzen dute sarera lagunarteko komunikazio premiak asetzeko, eta horrek agerian utzi du kode idatzi berri baten sorrera, komunikazio akademiko-formaletan erabiltzen denaren aldean aski desberdina. Sareko txatetan ekoizten dituzten elkarrizketak mintzidatziak direla esan daiteke; bat-batean sortuak, eta ahozko lagunarteko mintzamoldearen tankerakoak.

Aztertuak ditugu jadanik diskurtso mintzidatzi horien hainbat alderdi (Pérez \& Zulaika, 2014a, 2014b, 2016a), ahozkoaren eta idatziaren arteko harremana, idazkeraren ezaugarriak (alderdi grafikoa) eta adierazgarritasunaren zantzuak. Hona ekarri nahi duguna, berriz, txatetako (eta baita ahozko komunikazioko) beste ezaugarri bat da: euskararen eta gaztelaniaren arteko kode-aldaketa edo code-switching (CS) deitua. Alderdi honen azterketaren lehen urratsak emanak baditugu ere (Pérez \& Zulaika, 2016b), artikulu honetan zabal erakutsi nahi da txatgileek ekoizten dituzten mezuetako kode-aldaketaren ${ }^{1}$ tipologia ingurune sintaktikoa kontuan hartuta.

Zuzenean azterketari heldu aurretik, KA begiz jo duten lanak arakatu ditugu. Ikusiko denez, horietako asko ahozkoaren eremuan oinarrituak dira, eta agerian utzi dute, 
alde batetik, KA aski baliabide arrunta dela gazteen elkarrizketetan (Muñoa, 1997; Ibarra, 2011, 2014, 2018), eta, bestetik, kode aldizkatze horiek hizkuntzazko ezaugarri jakinak dituztela. Ingurune sintaktikoari erreparatuz, tipologia hirukoitza aztertu dute batzuek, eta KA intrafasikoa, interfrasikoa eta enblematikoa bereizi, Etxebarriak (2003), Ibarrak (2008, 2013, 2018), besteak beste. Perpaus barneko eremuan dihardute Epeldek eta Oiharçabalek (2010) eta perpausen artekoan Aurrekoetxeak eta Unamunok (2011). Ingurune horietaz baliatu gara gazteen diskurtso mintzidatziak aztertzeko eta ondorioztatzeko bat datozela ahozkoan eta sareko elkarrizketetan gazteek egin ohi dituzten kode-aldaketak.

Gazte euskaldunen hizkeraz ari garela, ezin baztertuzkoa da euskararen egoera soziolinguistikoak baldintzatua dela eta errealitatea askotarikoa dela euskararen hizkuntza komunitatean (Amonarriz, 2008). Hastapen modura-edo, errealitate horren zati bati soilik eutsi nahi izan diogu, eta hartarako hainbat lekutako gazteek sare bidez ekoitzitako elkarrizketak bildu eta haietaz baliatu gara KA aztertzeko. Esan gabe doa, erabateko ondorioak eta emaitzak aterako baditugu, errealitate soziolinguistiko bakoitzaren ispilu diren lagin zabalagoak ezinbestekoak direla. Gurea erakusgarri bat baino ez da, eta emaitzak ere maila horretan kokatu ditugu.

Bestalde, hemen kode-aldaketaren funtzio pragmatikoak alde batera utzi baditugu ere, arestiko lanean esanetako bat berresteko moduan behintzat bagaudela ondoriozta daiteke: diskurtsoetan kodea aldatzea gazte-identitatea moldatzeko baliatzen duten komunikazio-estrategietako bat da, arau akademiko formaletik urruntzeko eta desberdintzeko baliabidea (Amonarriz, 2008; Bereziartua, 2013; Etxebarria, 2003; Ibarra, 2011, 2018).

Ikerketa hau, berriz esan, KAren inguruan aztertuei egindako ekarria izatea nahi genuke: ahozko esparruan bezala, gazteek sareetan ekoitzitako elkarrizketen ezaugarri eta estrategietako bat da, alegia, haien hizkeraren bereizgarrietako bat. Ahozkoan baliatua bada, espero izatekoa da ahozko testu idatzietan ere -mintzidatzietan, alegiaerabiltzea.

Halaber, gazteen idatziz komunikatzeko gaitasunen berri zehatz eta zabalagoa emateko asmoarekin egina da. Eremu akademikoan gazteen komunikazio idatziaren ezaugarriak erakutsian jartzeko saioa egin ondoan (Pérez \& Zulaika, 2012), lagunartekoa begiz jo genuen. Ezin ukatuzkoa da, esparru akademikoan ez ezik, lagunarteko solasaldietan ere gazteek idaztera jotzen dutela, gizarte-sareek aukeran jartzen dizkieten tresnak baliatuta (Bereziartua, 2013). Ezinbestean jo behar dugu, beraz, komunikazio modu horretara, gazteen lagunarteko komunikazio idatziaren ezagutzan sakonduko bada.

\section{HURBILBIDE TEORIKOA}

Hizkuntzen arteko ukipenaren testuinguruan bizi diren hiztunek maiz jotzen dute hizkuntza-sistema batera baino gehiagotara berbaldiak moldatzeko. Hizkuntzaren eremuan diharduten ikertzaile askorentzat (hizkuntzalariak, soziolinguistak, komunikazioaren 
eta diskurtsoaren aztertzaileak) interes handikoak dira ukipenaren ondoriozko gertakariak, hainbat iker eremu eta ikuspuntu eskaintzen dituztelako: besteak beste, hizkuntzen arteko kontaktuaren ondorio diren interferentziak eta maileguak, kode-aldaketa edo alternantzia (code-switching) edo kode-nahasketa (code-mixing), hiztunen hizkuntzazko jarreren balioztapena, eta kodeak aldatzea edo txandakatzea eragiten duten arrazoiak.

Bereziki kode-aldaketaren inguruko ikerketak nahiko berankorrak dira, gainerako ukipenezko gertakariei eskainitakoekin alderatzen baditugu. Edonola ere, ikusgarritasun zantzuak nabaritu dira, eta batik bat 1970etik aurrera, elebitasunaren eremuko ikerketa askoren jomuga izan da diskurtsoan gertatzen diren kodeen arteko interakzioak (Sebba, 2012, 1. or.). Ildo horretan, aho batez onartua dute hainbat ikertzailek kode-aldaketa dela elebitasunaren aztergune behinena (Milroy \& Muysken, 1995) eta hura jo dute begiz beren lanetan. Lan horietako gehienek kode-aldaketaren testuinguruaren deskribapen soziolinguistikoak eta etnografikoak irudikatzen dituzte; beste batzuk, berriz, pragmatikaren eta elkarrizketaren analisiari eskainiak dira, eta baita kode-aldaketaren laginen azterketa gramatikalak eta ereduak ezartzeko arauen bilaketari ere (Gardner-Chloros, 2009, 10. or.). Ikuspegiak eta trataerak, beraz, askotarikoak dira.

Bestalde, auzi-sortzaile ere gertatu da izendapena bera. Esan daiteke ingelesezko bibliografian code-switching dela orokorrean termino zabalduena (ez adostuena, nolanahi ere, Appel \& Muysken, 1996, 119. or.). Gurera etorrita ere kode-alternantzia (Amonarriz, 2008; Ezeizabarrena, 2014; Ibarra, 2014, 2018...), kode-trukaketa (Rotaetxe, 1999) edo hizkuntza lerratzea (Epelde \& Oiharçabal, 2010), gisako izendapenak aurki daitezke han-hemen. Deizioak deizio, lan honetan kode-aldaketa edo alternantzia (KA) terminoaren aldeko hautua egin dugu aztergai dugun hizkuntza-gertaria izendatzeko. Hau da, hiztun elebidunek hizkuntza edo hizkuntza-aldaera bi (edo gehiago) aldizkatzen dituzte beren komunikazioetan (Etxebarria, 2003, 135. or.). Beraz, hizkuntza-sistema desberdinetako osagaiak diskurtso berean eta aldi berean izatea izango dugu jomuga. Hizkuntza-aldizkatze hori era askotara gauza daiteke mintzaldietan, dela mintzaldi bateko esaldietan edota esaldia baino beheragoko gramatikaosagaietan (Gardner-Chloros, 2009, 202. or.; Gómez, 1999-2000, 324. or.; Milroy \& Muysken, 1995, 7. or.).

Jarraian jasoko ditugu euskara-gaztelania kode-aldaketaren eremuan egileek aztertu dutena eta baita azterketa horietatik ateratako emaitza-ondorioak ere. Abiapuntu izango da guk hona ekarri duguna agerian jartzeko: ahozkoan bezalaxe, sareko elkarrizketetan ere gazteek kode-aldaketara jotzen dutela eta ingurune beretan baliatzen dutela hizkuntza aldizkatzearen estrategia hori.

\section{KODE-ALDAKETA GAZTE EUSKALDUNEN ELKARRIZKETA MINTZIDATZIETAN}

Kode-aldaketaren inguruko ikerketa gehienek testuinguru elebidunetan ekoitzitako ahozko corpusak izan dituzte aztergune (eleaniztunetan ere bai, Auerbach, 
2011, kasurako ${ }^{2}$ ) eta batik bat eremu informalean. Gumperz (1982, 59-99. or.) conversational code-switching terminoaz baliatu zen adierazteko, hain zuzen, KA ez dela soilsoilik elebitasunaren ezaugarrietako bat, baizik ahozko elkarrizketa elebidunarena.

Ahozkoaren aldean, diskurtso idatzia aztergune duten ikerlanak ez dira horren ugariak edo, akaso, ikusgarritasun gutxi izan dute hizkuntzen arteko ukipenezko analisietan. Zenbait ikerlanetan Gumperzen azterbidea -berez, plazaratutako hatsarreak ahozko jardunerako moldatu bazituen ere- baliatu da abiapuntu gisa, eta eremu idatzian aplikatu. Ildo horretatik abiatuta beste eredu batzuk sortu eta plazaratu dituzte -ahozkoaren eremukoak- hainbat ikertzailek, Myers-Scottonek (1993), Auerrek (1995, 1998) eta Weik (1998), besteak beste.

Nolanahi ere, komunikazio idatziaren esparruan KA oraindik ere azterkizun da (Sebba, 2012, 2. or.), baina oso litekeena da ohiko komunikazio moduak eta adierazpen idatziak irauli dituen teknologiari esker, esparru idatzi berriak begiz jotzea (blogak, mezuak, sareko webguneak...) eta haiek izatea KA idatzia ikertzeko arloak (MontesAlcalá, 2007, 162. or.).

Gure eremuan, euskararen eta gaztelaniaren (edo frantsesaren) arteko ukipenaren inguruan plazaratu diren lanak ugariak dira. Aztergai izan dira hiztun helduen diskurtsoetako interferentziak (Etxebarria, 2003; Muñoa, 1997; Rotaetxe, 1988, 1999...), haurren hizkerakoak (Barreña \& Ezeizabarrena, 1999, 2000; Barreña, Ezeizabarrena \& García, 2008...). Batez ere ahozko elkarrizketa informaletan KAren ispilu diren tipologiak eta funtzioak ere izan dira aztergai: gazte nafarrek ekoitzietan (Ibarra, 2008a, 2008b, 2009, 2011, 2013, 2014, 2018), Bilbo hiriguneko hiztun elebidunenetan (Lantto, 2014, 2015, 2016), euskaraz eta frantsesez mintzatzen diren hiztun helduenetan (Epelde \& Oiharçabal, 2009, 2010). Ikuspegi soziolinguistikotik egindako lanak ere badira, gazte euskaldunek beren komunikazioetan kode bat edo bestea (euskara eta/edo gaztelania) aukeratzeko arrazoiak zehazteko (Amonarriz, 2008; Soziolinguistikako Klusterra, 2011, 2012 ...). Guztietan ahozko corpusak aztertu dira ${ }^{3}$. Eremu idatziari dagokionez, aipagarria da Bereziartuaren (2013) eskola eremuko eta lagunarteko hizkuntza idatziaren azterketa, Azpeitiko gazteen hizkuntza ohiturak ikertzea duela jomuga. Besteak beste, gazteek gizarte-sareetan darabilten hizkeraren ezaugarriez dihardu; horietako bat, euskara-gaztelania KA.

Ikertzaileek euskara-gaztelania KAren azterketetatik ateratako emaitzetatik ondokoak nabarmendu nahi genituzke. Alde batetik, KA gazteek lagunarteko esparruan, ahoz zein idatziz, darabilten hizkeraren ezaugarrietako bat da; eskolan darabiltenetik urrundu eta identitate propioa garatzeko baliatzen duten hizkerarena, alegia.

2 Familia katalan batek katalanez, espainolez eta ingelesez ekoitzitako ahozko elkarrizketak aztertu zituen.

3 Ibarrak (2018, 187-192. or.) lanean ahozko corpusak hartzen ditu oinarri baina sareko elkarrizketari ere eskaintzen dio atal bat. 
Tipologiari dagokionez, batzuen ustez perpaus barnean gertatzen diren alternantziak beste ingurunetan gertatzen direnak baino konplexuagoak dira (Ibarra, 2018, 197. or.; Rotaetxe, 1999, 59. or.). Izan ere, alternantzia horiek eskakizun dute hiztunak bi hizkuntzetan gaitasuna izatea, kodeak aldatzeko nahitaezko baldintza baita diskurtsoan esku hartzen duten hizkuntza-sistemak errespetatzea eta haien gramatika-arauak ez urratzea. KA mota hau, gainera, bi hizkuntzetan gaitasun handiena duten hiztunen jardunean maizago agertzen omen da (Epelde \& Oiharçabal, 2010, 56. or.). Gogoan izan behar dugu KA honek eskakizun duela bi hizkuntzaren egiturak errespetatuak izatea (Poplack, 1980) ${ }^{4}$ eta, horrenbestez, erabiltzaileak bi hizkuntzak menderatzea, bietan hizkuntza-gaitasuna bereganatua izatea. Hain zuzen, hiztun elebidun gaituek arruntean perpausen barnean egin ohi dituzte kode-aldaketak eta horrexegatik dira gramatika-gaitasunaren erakusgarri ezin hobea. Perpausen arteko alternantzietan ere gaitasun hori bera aintzat hartu behar dela uste dute Aurrekoetxeak eta Unamunok (2011, 26. or. $)^{5}$. Bi ingurune horietan, bestalde, ohikoa izaten da osagai txertatua esaldiaren amaieran agertzea (Aurrekoetxea \& Unamuno, 2011, 26. or.; Ibarra, 2013, 126. or.).

Emaitza horiek kontuan hartuta moldatu nahi izan dugu gure ikerketa. Asmoa ez $\mathrm{da}$, jakina, hizkuntza gaitasunaren inguruko erabateko ondorioak ateratzea, lan honen mugak ez baitu horretarako ematen. Baina hona ekarri nahi dugunak badu berritasun bat: erabili dugun corpusa gazte euskaldunek ekoitzitako diskurtso mintzidatziek osatua da, eta ez ahozkoek. Arestian esan dugunez, gazteak maiz baliatzen dira gizartesareez solasean aritzeko, lagunarteko komunikazioa bideratzeko. Ekoizten dituzten elkarrizketak (txatak) aski bereziak dira: Ordenagailu Bidezko Elkarrizketa (OBE) (ingelesez CMC, Computer-Mediated Conversation) auzolanean eraikitako diskurtsoa da eta hiztunek elkarren artean komunikatzeko darabilten kode idatzia ahozko lagunarteko mintzamoldearen ispilua da, testu mintzidatziak dira, alegia. Diskurtso horietan oin hartuko dugu eta gazte elebidunek lagunarteko testuinguru horretan sortzen dituzten elkarrizketetatik abiatuko gara euskara-gaztelania KA aztertzeko.

Esan gabe doa hiztun elebakarretan ere hizkuntza-aldaerak aldi berean gerta daitezkeela haien mintzaldietan (aldaera diastratikoak, esaterako), baina lan honetan hiztun elebidunenetan antzematen diren hizkuntza-ukipenak bakarrik hartuko ditugu kontuan.

4 Lan honetan ez ditugu berariaz aztertuko murriztapenak baina gogoan izatekoak dira Poplackek ezarritakoak: 1. Morfema askearen murriztapena (the free morpheme constraint): kode-aldaketarik ezin gerta daiteke elkarren mendeko diren morfemetan. 2. Murriztapen baliokidea (the equivalence of structure constraint): kode-aldaketak ezin ditu inola ere bi hizkuntzetako arau sintaktikoak hautsi, eta, horrenbestez, egitura baliokideak diren kasuetan soilik gerta daitezke. Rotaetxek $(1999$, 64. or.) beste murriztapen bat ere aipatzen du, perpauseko osagaien hurrenkerari dagokiona. Ibarrak $(2018,198$. or.), beste hainbat ikertzaileren bidetik, auzitan jartzen du murriztapen horien zurruntasuna. Aurrekoetxeak eta Unamunok (2011, 26. or.) ere murriztapen auziaz dihardute.

5 Mendeko perpausetan, esaterako, euskararen eta gaztelaniaren egiturak ez datoz bat, eta horrek eskakizun du hizkuntza mugak kontuan hartzea. 


\section{AZTERBIDEA ETA LAGINAREN EZAUGARRIAK}

Gaur egun, Ordenagailu Bidezko Diskurtsoaren (OBD) inguruko azterketak gero eta ugariagoak dira, aldez behintzat Corpusaren linguistikaren garapenak ateak zabaldu dizkielako azterbide egokiak aplikatzeko, testu naturalak eta osoak jasotzeko joerari esker. Sare bidezko esparru horretan ekoizten diren testu naturalak bildu eta ezaugarri linguistikoak eta diskurtsiboak agerian jartzea ahalbidetzen du, eta horrek berekin dakar gizarte-sareetako komunikazioaren ezagutzan sakontzeko aukera.

Esparru horretako corpusak eraikitzeak hainbat abantaila ditu: azterketa kuantitatiboak eta kualitatiboak egiteko aukera, datuak berreskuratzeko erraztasuna (euskarri digitalizatuari esker), laginaren zabala eta, batez ere, bildutako testuen izaera naturala, horrexek ematen baitie fidagarritasuna analisiari eta emaitzei. Zailtasunak ere baditu: testuen zabalak eta heterogeneotasunak ezinbestean dakar irizpideak ezartzea lagin adierazgarria lortu eta aurretik ezarritako helburuetara iritsiko bagara (Mancera \& Pano, 2014, 306. or. $)^{6}$.

Gure aztergaiari dagokionez, datu naturalen corpusaren analisia azterbide garrantzitsuenetakoa da kode-aldaketaren ezaugarrien berri emateko. Horren erakusgarri da Poplackek (1980) abian jarritako ikerketa; hura abiapuntu hartuta, hainbat ikertzailek ekin diote kode-aldaketaren alderdiak aztertzeari (Munarriz \& Parafita, 2014, 47. or.). Alde horretatik, gure azterketaren aurrekoek -besteak beste arestian aipatutako Lantto eta Ibarrarenak- euskara-gaztelania KA aztertzeko ezarri dugun helburuarekin, prozedurarekin eta emaitzekin bat egiten dutela esango genuke.

Aurretiaz adierazitakoak hartu ditugu gogoan geure corpusa osatzeko eta uste dugu lagin aski adierazgarria dela ezarri dugun helburura iritsi eta emaitzak ateratzeko. Hainbat lekutako gazte euskaldunek eskura jarri dizkiguten solasaldiak dira gure laginaren oinarria, Tuenti y WhatsAppen ekoitzitako txat idatziak ${ }^{7}$. Elebidunak dira eta euskaraz heziak ${ }^{8}$ lagunartean eta familia giroan (Eusko Jaurlaritza, 2016, 14. or.). Euskaraz eta gaztelaniaz hainbat erregistrotan aritzeko gaitasuna dute: ahozkoa eta idatzia, formala (formala) eta lagunartekoa (informala). Gehienak unibertsitateko ikasketak egiten ari dira. Ohartarazi behar dugu, hala ere, profilaz jaso ditugun datuekin ezin ondoriozta dezakegula gaitasun horren maila zenbaterainokoa den. Ikuspegi soliolinguistiko zabalagoa hartuko luketen ikerketak beharko genituzke ondorio erabatekoak ateratzeko.

6 Ildo horretan kokatzekoa da, esaterako, Ibarraren (2015) lana. Jomuga bikoa da: alde batetik, gizarte-sareetatik hartutako corpusa txikia osatu eta euskal erabiltzaileek ekoizten dituzten testuen (hizkeraren) hainbat hizkuntza-ezaugarri aztertzea (ahozkoaren ezaugarriak, euskalkien aztarnak...); bestetik, agerian jartzea gizarte-sareen baliagarritasuna hizkuntzazko azterketa hori egiteko.

7 Euskal Autonomia Erkidegoko VI. Inkesta Soziolinguistikoaren datuen arabera, 16-24 urte bitarteko gazteen $\%$ 29,5ek euskara maiztasun handiz erabiltzen du Interneteko gizarte-sareetan (Eusko Jaurlaritza, 2016, 25. or.).

8 Lanttok (2015, 2016) Old Basque deitzen dituenak; horien ondoan, New Basque deituak hiztun berriak dira, euskara hezkuntzako murgiltze goiztiarreko ereduetan ikasi dutenak (Amorrortu, Goirigolzarri, Ortega \& Urla, 2016). 
Lagina EAEko eta Nafarroako hainbat lekutako aniztasun geolinguistikoaren erakusle da. Tuentiko erabiltzaileak 47 dira, 14 eta 25 urte bitartekoak (32 emakumezkoak eta 15 gizonezkoak): 16 bizkaitarrak $^{9}, 25$ nafarrak $^{10}, 5$ gipuzkoarrak ${ }^{11}$ eta lapurtar bakarra (Bilbon bizitakoa). WhatsAppeko talde bateko erabiltzaileak 10 neska dira, 18 eta 20 urte bitartekoak eta unibertsitateko ikasleak guztiak. Beste talde batean 12 mutil dira, horiek ere adin tarte horretakoak ${ }^{12}$. Elkarrizketa gehienak geolekto bereko hiztunen artekoak dira. Baina WhatsAppeko talde bateko elkarrizketak Euskal Herriko 9 herritako neska gazteek eginak dira ${ }^{13}$.

Eskura jarri dizkiguten elkarrizketak 84 dira, bakoitza 3 orrialdekoa; lagina, guztira, 252 orrialdekoa da. Elkarrizketak ez dira azterketa honetarako berariaz sortuak, baizik ohiko modu arruntean egindakoak ${ }^{14}$. 2012ko abuztuaren 1ekoa da elkarrizketa aspaldikoena (Tuentikoa) eta 2015 eko apirilaren 18koa berriena (WhatsApp).

Corpusak emaitza interesgarriak emango dituelakoan bagaude ere, jakitun gara mugak ere badituela eta ezinbestekoa dela erabiltzaileen tipologiazko azterketarekin osatzea -euskalkiaren araberakoa ez ezik, euskararen jabekuntzazkoa ere bai, bai eta Hegoaldeko eta Iparraldeko gazte elebidunen arteko elkarrizketekin ere-, hiztun komunitatearen errealitate soziolinguistikoa askotarikoa dela aintzat hartuta. Horrek guztiak zehatzago ispilatuko gazteen lagunarteko erregistroa, euskal erregistro batua.

\section{EUSKARA-GAZTELANIA KA. INGURUNE SINTAKTIKOAREN ARABERAKO TIPOLOGIA}

Testuinguru elebidunetan ohikoa izaten da ukipeneko hizkuntzetako bat diskurtsoan nagusi edo oinarrizkoa izatea (H1) (interaction language, Auer, 1988, 200. or.; matrix language, Myers-Scotton, 1995, 234. or.) eta bestea, berriz, hizkuntza txertatua (H2) (embeddeed language, Appel \& Muysken, 1996, 182. or.). Epeldek eta Oiharçabalek (2010, 56. or.) matrize hizkuntza eta txerto hizkuntza terminoak darabiltzate, hurrenez hurren.

H1 zein den erabakitzeko irizpide bat baino gehiago daude, hiztunak gaitasun handiena erakusten duen hura, besteak beste. Appelen eta Muyskenen (1996, 182. or.) arabera bi ikuspegik definitzen dute oinarrizkoa: soziolinguistikaren ikuspegitik, H1 edo

9 Abadiño, Berriz, Bilbo, Igorre, Mallabia, Mundaka, Ondarroa, Zornotza. 14-22 urte bitarteko hiztunak. 9 emakume eta 4 gizon. 22 elkarrizketa; guztiak bizkaitarren artekoak dira.

10 Arantza, Baztan, Doneztebe, Elgorriaga, Iruñea, Leitza, Lesaka, Saldias. 15-25 urte bitartekoak. 11 emakume eta 11 gizon. 22 elkarrizketa; elkarrizketa guztiak nafarren artean.

11 Horien artean, Tuentikoak 2 emakume azpeitiar dira, 20 urtekoak. Elkarrizketak beren artean izan dituzte. 10 elkarrizketa.

12 Azkoitiko 2, Getariako 2, Zumaiko 1 eta Zarauzko 7. 15 elkarrizketa.

13 Euskal Herriko 9 herri hauetakoak: Añorga, Arizkun, Arrigorriaga, Baiona, Galdakao, Irurtzun, Oiartzun (bi hiztun), Zaldibia, Zubieta (Nafarroa). 15 elkarrizketa.

14 Guztiei eskerrak eman beharrean gara. 
matrize hizkuntza diskurtsoaren egoera definitzen duena da; testuinguru jakin bateko hizkuntza-kode ez markatua da; ikuspegi psikolinguistikoari jarraituz, kodea aldatzen duen hiztun elebidunaren hizkuntza nagusia da, ondoen menderatzen duena. Adierazten dute, halaber, KA gertatzen denean, oinarrizko hizkuntzak (H1) ezartzen dituela murriztapen gramatikalak, eta ez besteak.

Nolanahi ere, inoiz zail samarra izaten da zehaztea zein den oinarrizkoa (Pérez \& Zulaika, 2016b). Gazteen elkarrizketa batzuetan, izan ere, euskara eta gaztelania ia pare-parean daude:

(1) pero eske medikuek esaoztan ke si me ponia alli otra bez mal ke seria peor ta seria asi ze gaur arte bakarrik eon na eraten likidue ta jaten un poko de arroz ta gaur e komido sopa y otra vez me a enpezau un poko dolor de tripas...

Bestalde, aipatzekoa da aztergai izan ditugun ia kasu guztietan $\mathrm{H} 1$ eta $\mathrm{H} 2$ ren arteko harremana asimetrikoa dela, beti ere gaztelaniaren aldekoa, hortik hartuak eta euskarazko diskurtsoan txertatuak baitira nagusi. Kontrako kasu gutxienetan, erabiltzaileek gaztelania oinarrizko hizkuntza gisa darabiltenean $(\mathrm{H} 1)^{15}$, alegia, euskaratik $(\mathrm{H} 2)$ hartuak izen sintagmak soilik dira: lau agerraldiko talde eta agerraldi bakarreko taldekide eta sarreras.

(2) Aaaaa y lo de los taldess... yo me pidoo a patri como taldekidee jajajja

(3) pa una ke nos kedamos haciendo fiesta aki va y dos sarreras gratis??

Kasu bakan horiek bazter utzita, euskarazko diskurtsoan txertatzen diren gaztelaniako elementuak izango ditugu aztergune. Arestian adierazien bidetik, hainbat ikertzailek baliatutako azterbidea hautatu eta hiru KA mota bereiziko ditugu: perpaus barnekoa (edo intrafrasikoa), perpausen artekoa (edo interfrasikoa) eta enblematikoa.

\subsection{Perpaus barneko KA}

Perpausaren barnean gertatzen diren kode-aldaketen artean biltzen dira, besteak beste, atribuziozko perpausak (Ibarra, 2013) eta preposizio sintagmak (Epelde \& Oyharçabal, 2009).

Aztertutako elkarrizketetan, perpaus barnean H2ren elementuok txertatzen dira: 1) super-aurrizkia, 2) atributua eta 3) izen sintagma edo preposizio sintagma.

1) Hanpatze funtzioa berezkoa duen super-aurrizkia ageri da oinarrian gaztelaniako adjektiboa edo adberbioa duela:

(4) egon naiz aste guzia super liada; super lotsatute; super polite

15 Oinarrizko hizkuntza gaztelania duten elkarrizketen azterketa lan honetatik kanpo utzi dugunez, ez dugu berariazko laginik moldatu baina halako gertariak izan badirela adierazi nahi izan dugu. 
2) Izan eta egonekin moldatutako egiturak. Atributu txertatua perpausaren amaieran ageri da (Ibarra, 2008b; 2013, 119. or.).

(5) neskak!!! ga mas listass........

(6) Nazzzz una champiiiioooooonssSSS

(7) eta da mui mitiko

(8) Benetan... dau super txadto

(9) Gainera puff nauu comoo egun txarragazz

Lanttok $(2014,761$. or.) adierazi bezala, kode-aldaketa gaztelaniazko hurrenkera ez markatuan adierazten da -aditza atributuaren aurretik- eta ez euskararen berezko ordenan -arruntean, ordena neutroa izaten da, aditza perpausaren amaieran kokatua-.

3) Sintagma txertatuak bi eratakoak izan daitezke: determinatzaile sintagma edo preposizio sintagma; a, por, en, como, para, con, de eta en preposizioekin moldatuak dira bigarrenak.

Ohikoena da sintagma horiek aditzaren ondotik txertatzea, perpausaren amaieran, izen sintagmen ondoko adibideetan ikusten den bezala:

(10) ta kustera el cine d verano pixket!!!!

(11) ta seuro kusten dzula algun famoso!!!!!

(12) kusi ginun la d ls simios

Beste horrenbeste gertatzen da preposizio sintagmetan:

(13) nik defendittuko dut a muerteee!!!

(14) gan bar zra a $x$ todas

(15) barkatu atzendu zait por completo

(16) ta momentun ongi [...] lanin atope como si nada

(17) kriston zandali pilla pa nada!

Hurrenkera kontuak alde batera utzita, (13-17) adibideetako batzuk gaztelaniako esapidetzat jotzekoak direla esango genuke. Hain zuzen, pentsa daiteke gaztelaniako esapideak izateak -zenbaitetan euskal ordain zuzenik gabeak- azalduko lukeela hizkuntza horretara jo izana. Nolanahi ere, agerikoa ere bada bestetan erdal sintagmak adierazia -arestiko (10-12) bitartekoak barne- euskaraz emateko modua izango zukeela erabiltzaileak, eta, halaz ere, kodea aldatzera lerratu da:

(18) ta seguro kruzatu naizela con algun deportista

(19) Uain ya desblokeatu diot tuentitik, ta ya badut como desconocido;

(20) aittu dut,., en una tienda de zapatos en Iruña!

(21) nola gan ginen a la ultima sesion ordu bata terdietan akitu zen 
Akaso hiztunek ez lukete eragozpenik «kirolariren batekin», «ezezagun bezala», «Iruñeko oinetako denda batean», «azken saiora»... gisakoak adierazteko baina diskurtsoari kutsu informala eta adierazkorra emateko baliatu dira H2ko txandakatzeez.

\subsection{Perpausen arteko KA}

H2ko esaldi osoak txertatzen dira H1en diskurtsoan (Aurrekoetxea \& Unamuno, 2011; Ibarra, 2011, 283. or., 2014, 31. or.; Redouane, 2005; Rotaetxe, 1988).

Juntaduran maiztasun handikoak diren emendiozko eta aurkaritzako perpausetan euskal eta erdal juntagailuak (eta/y, baina/pero) txandakatzen dira. Ondoko adibideak irudikatzen du baña eta pero juntagailuen erabilera perpausak elkartzeko:

(22) gustora sobera petau baña mejor k vacio!!!! atzo etzinen atra???ostatuek maten zuten pena pixket... ta gan bar nintzen lurrera pro viendo lo $k$ abia etxera direkto!!!

Adibide ugarik erakusten dute txatgileak berdin darabilela juntagailua gaztelaniaz nahiz euskaraz:

(23) san bar diot X-i grabatzeko esne beltzan diskua aste hontan ta si hacemos fundamento te grabo y te paso ok?

(24) behar dt 4 bt aprbatzeko y veo $k n$ voy a sacar!!!

(25) uste dut moztu dula illia y esta muy fea

(26) ostegunin nahi nun atra baña me da k nadie se va animar

(27) aitu dut ingenieriak direla naiko zaiak... pero solo son rumores

Mendeko perpaus txertatuen artean, osagarriak, kausazkoak, baldintzazkoak eta erlatibozkoak gailentzen dira. Maiztasun handiagokoak dira, bereziki, aurretik gaztelaniako que duten perpaus osagarri txertatuak.

(28) ta atzo ze muxa fiesta??? erran zdten $k$ andabs $x$ la totem

(29) kusi dt k tengo $k$ darle ms kaña...

(30) badakixu ke no me parecen las mejores formas

Kausazko perpausetan maizenik que eta porque darabiltzate; lehena erlatibozkoetan ere ageri da:

(31) biño neri ez kontatu yaus, que igual te mato ahí mismo.

(32) asike zu lasai, q lo sacaras a la segunda!

(33) ez nintzen gan $x k$ abia k descansar

(34) gaten al zra ere kale bateera $k$ hay todo cines!!!!

Baldintza perpausetan, azkenik, gaztelaniako apodosia edo baldintzaren ondorioa euskarazko diskurtsoan txertatuta ikus daiteke eta baita gaztelaniako baldintza ere, hurrenez hurren: 
(35) gañera lurrera ez bada gaten jendia aurten el proximo año no abre!!!

(36) orain hasiko naiz itten. abistuko dizut si tengo muchas dudas

\subsection{KA enblematikoa}

Tipologia honetakoak dira interjekzioak, harridurak eta hitz gordin edo itsusiak (Gumperz, 1982), makulu hitzak eta elementu diskurtsiboak (Ibarra, 2011, 281. or., 2014, 33. or., 2018, 202. or.; Moreno Fernández, 1998, 269. or.). Oso sarri jotzen dute txatgileek KA mota honetara.

(37) Meeenkantaaaaaaaa!!!

(38) Gora gu ta gutarrak la ostia!

(39) motza da lana joder... zeoze entregokot

(40) Sin mas aukera bat

(41) Pues nada zorte on azterketetan

Sail honetakoak dira, halaber, diskurtsoaren hasiera-bukaerak adierazteko eta diskurtsoaren sekuentziek jarraipena izateko darabiltzaten hainbat baliabide. Gaztelaniaz ez ezik, ingelesez eta frantsesez ere ageri dira.
(42) Helloou neskak!!
(43) jun komentetan ok?
(44) Ei pipol
(45) See you my pringy friend!
(46) Alo alo neskatxiek!!

Txatgile batzuek H1en amaieran H2ko galdera-perpausak txertatzen dituzte.

(47) gaztetxin elkartzen bagara? Ke dizes?

(48) afaldu eta gero urtetie Ke os parece?

(49) baña bueno jun geinke begitzen goizen baten edo albozu!! Te parece??

Perpaus horiek darabiltzate solaskidearen arreta bereganatzeko, haren onarpena, erantzuna edo iritzia lortzeko; bestela esanda, elkarrizketa zabalik mantentzeko. Eginkizun konatibo edo deigarrien adierazpideak ohikoak izaten dira lagunarteko elkarrizketetan eta, hortaz, txatetako mezuetan ere gauzatzen dira etengabeko harremanari eusteko eta elkarri eragiteko (Pérez \& Zulaika, 2016a, 107. or.).

Ildo horretakoak dira corpusean atzeman ditugun testu-antolatzaile eta konektore asko: pues, ya, yasta, (e)ske, osea, asike, keba, bale, bueno, klaro ${ }^{16} \ldots$

16 Testu-antolatzaileak eta konektoreak aztertuak ditugu zabal Pérez eta Zulaika (2014b) lanean. 
(50) inprimatuko dot yaa

(51) Asike ez dakit

(52) Osea zentratu daiteke

(53) Bueno sin+ animetan bazara

(54) Baiii hurrengoaan fijooo

(55) Keba! laixterka!!

(56) da en plan carrera

Pérezek eta Zulaikak (2016a, 2016b) adierazi bezala, markatzaile batzuk ez dira gazteen hizkeran soilik erabiltzen -pues, asike, o sea, eske...-, dela ahozko elkarrizketetan dela txatetan, baizik hiztun elebidunen jardunaren ezaugarri komuntzat har daitezke. Beste batzuk, berriz, gazteen hizkera-hautuari dagozkiola esan daiteke; erabilera markatuagoa dute: sinmas, fijo, bale, benga, si eso, keba, en plan ${ }^{17} .$.

Inoiz gerta daiteke erabiltzaileak nahiago izatea markatzaile bat edo bi (eske eta pues, kasurako) eta horiexek soilik baliatzea elkarrizketa moldatzeko. Lanttok (2015, 754. or.), dioenez badira KAren eredu finkatuak, conventionalized code-switching (Muysken, 2000tik hartutako terminoa) osatzen dutena; alegia, komunitate bateko hiztunek onartzen eta partekatzen duten elementu eta egitura multzoa. Euskaragaztelania KAn behin eta berriz errepikatzen dira H2ko elementu batzuk (markatzaile pragmatikoak, hitz gordinak eta lagunarteko bestelako adierazpideak...) gazte euskaldunen diskurtsoetan eta KAren eredu egonkortuak bihurtzen dira komunitate elebidunetan. Hori dela eta, beharrezko ikusten du conventionalized code-switching nozioa, kodeak aldatzean ageri diren erregulartasunen berri emateko eta beste hizkuntzetako elementuek H1ean ageri duten integrazio maila azaltzeko (Lantto, 2015, 766. or.).

\section{ONDORIOAK}

Artikuluaren hasieran adierazia ekarriko dugu hona: kode-aldaketa aski arrunta da euskal gazte elebidunen elkarrizketetan (Muñoa, 1997; Ibarra, 2011, 2014, 2018; Pérez \& Zulaika, 2016b); ahozko jardunean ez ezik, aztergai izan ditugun gizarte-sareetako elkarrizketa idatzietan ere jotzen dute kodea aldatzera. Bestela esanda, ahozkoaren eremuan aztertuak eta adieraziak osatu nahi izan ditugu beste eremu bat begiz jota, gizarte-sareen esparrua, eta ondoriozta daiteke hor ageri diren hizkuntza aldizkatzeak ahozkoan ekoitziakoaren parekoak direla.

Aztergaia moldatzeko hizkuntzaren erabilera naturalaren ekoizpenez baliatu gara, sareetan ekoitzitako diskurtsoez, alegia. Analisiak erakutsi digu gazteen komunikazio elebidunetan euskara-gaztelania KA ohiko ezaugarria dela, erabiltzaileek auzolanean

17 Gisa horretako esapide proposizionalak markatzaile pragmatikoak bihurtzeko bidean dirateke (Lantto, 2015, 759. or.). 
eraikitako diskurtsoan onartua; areago, sortzen ari diren kodearen alderdi berritzailea eta berezko estiloa duena antzeman daiteke, gazteen identitatearen erakusgarri. Hitz batean esanda, KA gizarte-sareetako lagunarteko esparruan komunikatzeko moduaren ezaugarri behinenetako bat da. Hain zuzen, komunikazio egoeraren formaltasuna eta erabiltzailearen gizarte identitatea (talde identitatea) izan ohi dira kodea aldatzearekin zuzenenean uztartu ohi diren faktoreetako batzuk (Amonarriz, 2008; Bereziartua, 2013...).

Bestalde, agerian jarri dugu erabiltzaileak gai direla H1eko ingurune sintaktikoetan H2ko elementuak txertatzeko. Esan gabe doa, hortaz, Poplackek (1980) adieraziaren bidetik, KA ez dela hizkuntzaren hutsuneak edota gaitasun urriko hiztunak komunikatzeko darabilen baliabideetako bat, alderantzizkoa baizik: berariaz moldatutako estrategiatzat jo daiteke, hainbat egilek erakutsi duten bezala.

Ingurune sintaktikoaren araberako tipologian hiru KA mota bereizi ditugu: perpaus barnekoa, perpausen artekoa eta enblematikoa. Perpaus barnekoetatik nabarmen daitezke H2ko izen eta preposizio sintagmen txertatzeak. Batzuk gaztelaniako esapideak, euskal ordainik gabeak, izan daitezke, eta kodea aldatzea, beraz, hutsune hori betetzeko estrategia. Nolanahi ere, kasu askotan ez da hala, eta euskaraz emateko modua izanik ere H2ra jotzen du erabiltzaileak. Perpausen artekoetan, berriz, emendiozko eta aurkaritzako juntaduran, batez ere, gailentzen da kode-aldaketa, eta H2ko que konjuntzioaz baliatuta txertatutako mendeko perpausak. Agerikoa da, horrenbestez, egituraren aldetik horren urrun dauden hizkuntzak izanik ere, gazteentzat hori ez dela, inondik ere, behaztopa-harria euskararen eta gaztelaniaren arteko kode-aldaketa gertatzeko.

Azkenik, KA enblematikoari dagokionez, maizenik erabilia delakoan gaude. Kasuistika zabal samarra ageri duen arren, saiakera egin dugu txertatzen diren elementu gailenak jasotzeko: interjekzioak, testu-antolatzaileak, hitz gordinak eta irainak, eginkizun konatiboa duten elementuak... Ahozko jardunean nabari daitekeen H2ko elementu diskurtsiboen ugaritasuna erakusten dute txatetako elkarrizketek; adierazi dugu, halaber, batzuk ahozkoan baliatuak ez ezik, gazte-hizkeraren ezaugarri berariazkoa izan daitezkeela. KA enblematikoaren gailentze horren oinarrian legoke, gure ustez, komunikazio egoera bera, haren formaltasun eza eta hizkuntza generoa bera (elkarrizketa).

Hainbat ikertzailek agerian jarri dituzten ahozko eremuko KAren ezaugarriak izan ditugu gogoan, eta ondorioztatu dugu -aurreragoko lanek berretsiko dutelakoan-sareko elkarrizketetan ere antzeman daitezkeela ezaugarri horiek berak.

Esan gabe doa, bestalde, gazte euskaldun elebidunek diskurtso originala eta kolore bizikoa darabiltela gizarte-sareetan gauzatzen dituzten komunikazio interakzioetan, eta horretarako kodeak aldatzea, besteak beste, baliatzen duten estrategietako bat dela.

Aitor dugu, lanaren luze-laburrak eraginda, hainbat alderdi bazter utzi behar izan ditugula: alde batetik, tipologiarekin batera, nahitaezkoa da funtzio pragmatikoak eta gazteak kodeak aldatzeko dituzten arrazoiak aztertzea -tarteka aipamenen bat edo 
beste eman badugu ere- KAren ikuspegia osatzeko; bestetik, soziolinguistikaren alderdiari begiratuta, gure errealitate geolinguistikoaren lagin labur baina ustez adierazgarriaz baliatu gara, baina jakitun gara aurreragoko ikerketetarako datu-bilketa zabalagoa beharko genukeela. Hala eta guztiz ere, hemen aztertuak gazteen hizkerako KAren berri zabalagoa emango duelakoan gaude.

\section{ERREFERENTZIAK}

Amonarriz, K. (2008). Gazte hizkerak-hizkera gazteak. Bat Soziolinguistika aldizkaria, 68(3), 167-183.

Aurrekoetxea, G. \& Unamuno, L. (2011). Perpaus arteko euskara-gaztelania kode-aldaketa. Euskalingua, 19, 25-30.

Amorrortu, E., Goirigolzarri, J., Ortega, A. \& Urla, J. (2016). Euskal hiztun berriak: esperientziak, jarrerak eta identitateak. Bilbo: Deustuko UnibertsitateaBizkailab.

Appel, R. \& Muysken, P. (1996). Bilingualismo y contacto de lenguas. Bartzelona: Ariel. Auer, P. (1988). A conversation analytic approach to code-switching and transfer. In M. Heller (arg.), Codeswitching: anthropological and sociolinguistic perspectives (187-213. or.). Berlin: Mouton de Gruyter.

Auer, P. (1995). The pragmatics of codeswitching: A sequential approach. In L. Milroy \& P. Muysken (arg.), One Speaker, Two Languages, Cross-disciplinary Perspectives (115-135. or.). Cambridge: Cambridge University Press.

Auer, P. (1998). Code-Switching in conversation. Language, interaction and identity. Londres \& New York Routledge.

Auerbach, J.S. (2011). No sé qué day: Code-switching and code-mixing in a plurilingual family living in Catalonia. Bellaterra Journal of Teaching and Learning Language \& Literature, 4, 72-93.

Aurrekoetxea, G. \& Unamuno, L. (2011). Perpaus arteko euskara-gaztelania kode-aldaketa. Euskalingua, 19, 25-30.

Barreña, A. \& Ezeizabarrena, M. J. (1999). Acquisition bilingue: séparation ou fusion des codes linguistiques? In F . Favereau (arg.), Le bilinguisme précoce. En Bretagne, en pays celtiques et en Europe atlantique (225-245. or.). Rennes: Presses Universitaires de Rennes. (Klask, 5).

Barreña, A., Ezeizabarrena, M. J. \& García, I. (2008). Influence of the linguistic environment on the development of the lexicon and grammar of Basque bilingual children. In C. Pérez-Vidal, M. Juan-Garau \& A. Bel (arg.), A Portrait of the Young in the New Multilingual Spain (86-110. or.). Clevedon, UK: Multilingual Matters.

Bereziartua, G. (2013). Ingurune euskalduneko gazteak eta hizkuntza idatzia, eskolan eta eskolatik kanpo. Bat Soziolinguistika aldizkaria, 89(4), 25-42.

Epelde, I. \& Oyharçabal, B. (2009). «Code switching» en las variedades orientales del vasco. Iker, Artxiker artxiboa. http://artxiker.ccsd.cnrs.fr/artxibo-00389939 helbidetik berreskuratua.

Epelde, I. \& Oyharçabal, B. (2010). Perpaus barneko hizkuntza lerratzeak (HL) ekialdeko euskal elebidunetan. ASJU, 52, 55-64. 
Etxebarria, M. (2003). Español y euskera en contacto. Lingüística en la red, 1, 1-16. http://www.linred.es/articulos_pdf/LR_articulo_10072003.pdf helbidetik berreskuratua.

Eusko Jaurlaritza. (2016). Euskal Autonomia Erkidegoko VI. Inkesta Soziolinguistikoa. http://www.euskadi.eus/contenidos/informacion/argitalpenak/es_6092/ adjuntos/Resumen_VI_Encuesta_Socioling\%C3\%BC\%C3\%ADstica_ EAE_\%202016_1.pdf helbidetik berreskuratua.

Ezeizabarrena, M. J. (2014). Kode alternantzia elebidun txikien hizkuntzak bereizteko gaitasunaren adierazgarri. In M. J. Ezeizabarrena \& R. Gómez (arg.), Eridenen duzu zerzaz kontenta. Sailkideen omenaldia Henrike Knörr irakasleari (1947-2008) (207-225. or.). Bilbo: EHuko Argitalpen Zerbitzua.

Gardner-Chloros, P. (2009). Code-switching. Cambridge: Cambridge University Press.

Gómez Molina, J. R. (1999-2000). Transferencia y cambio de código en una comunidad bilingüe. Área metropolitana de Valencia (I, II). Contextos, 33-36, 309-360.

Gumperz, J. J. (1982). Discourse Strategies. Cambridge: Cambridge University Press.

Ibarra, O. (2008a). Sobre estrategias discursivas del lenguaje de los jóvenes vascoparlantes: aspectos pragmáticos y discursivos (conectores, marcadores). In X. Artiagoitia \& J. A. Lakarra (arg.), Gramatika jaietan Patxi Goenagaren omenez (395-411. or.). Bilbo: UPV/EHU. (ASJUren Gehigarriak, 51).

Ibarra, O. (2008b). Apuntes sobre interferencia castellano-vasca en el lenguaje juvenil actual. Léxico, calcos y transferencia lingüística. Oihenart, 23, 219-240.

Ibarra, O. (2009). Gazte-hizkerari buruzko ohar batzuk. Euskonews, 498. http://www. euskonews.com/0498zbk/gaia49804eu.html helbidetik berreskuratua.

Ibarra, O. (2011). Sobre estrategias discursivas de los jóvenes vascohablantes: causas que motivan el cambio de código. Oibenart, 26, 277-298.

Ibarra, O. (2013). El code switching vasco-castellano en oraciones atributivas de hablantes jóvenes. Oihenart, 28, 115-130.

Ibarra, O. (2014). Tipología y pragmática del code-switching vasco-castellano en el habla informal de jóvenes bilingües. Lapurdum, 18, 23-40.

Ibarra, O. (2015). Sare sozialak, euskalkiak ikertzeko baliabide gisa. Lapurdum, 3, $155-175$.

Ibarra, O. (2018). El euskera de ayer y hoy: variación y contacto. Iruñea: Pamiela.

Lantto, H. (2014). Code-switching, swearing and slang: The coloquial register of Basque in Greater Bilbao. International Journal of Bilingualism, 18(6), 633-648.

Lantto, H. (2015). Conventionalized code-switching: Entrenched semantic-pragmatic patterns of a bilingual Basque-Spanish speech style. International Journal of Bilingualism, 19(6), 753-768.

Lantto, H. (2016). Conversations about code-switching: contrasting ideologies of purity and authenticity in Basque bilinguals'reactions to bilingual speech. Multilingua, 35(2), 137-161.

Mancera, A. \& Pano, A. (2014). Las redes sociales como corpus de estudio para el análisis del discurso mediado por ordenador. Humanidades Digitales: desafíos, logros y perspectivas de futuro. Janus, anexo 1, 305-315.

Milroy, L. \& Muysken, P. (1995). One Speaker, Two Languages, Cross-disciplinary Perspectives. Cambridge: Cambridge University Press. 
Montes-Alcalá, C. (2007). Blogging in Two Languages: Code-Switching in Bilingual Blogs. In J. Holmquist, A. Lorenzino \& L. Sayahi (arg.), Selected Proceedings of the Third Workshop on Spanish Sociolinguistics (162-170. or.). Somerville, MA: Cascadilla Proceedings Project. http://www.lingref.com/ cpp/wss/3/paper1537.pdf helbidetik berreskuratua.

Moreno Fernández, F. (1998). Principios de sociolingüistica y sociología del lenguaje. Bartzelona: Ariel.

Munarriz, A. \& Parafita, M. ${ }^{a}$ C. (2014). ¿Cómo estudiar el cambio de código? Incorporación de diferentes metodologías en el caso de varias comunidades bilingües. Lapurdum, 18, 43-73.

Muñoa, I. (1997). Pragmatic functions of code-switching among Basque-Spanish bilinguals. In M. C. Cabeza, A. M. Lorenzo, X. P. Rodríguez (arg.), Actas do I Simposio Internacional sobre o Bilingüismo (528-541. or.). Vigo: Universidad de Vigo.

Muysken, P. (2000). Bilingual speech: A typology of code-mixing. Cambridge: Cambridge University Press.

Myers-Scotton, C. (1993). Social motivations for codeswitching: evidence from Africa. Oxford: Oxford University Press.

Myers-Scotton, C. (1995). A lexical based model of code-switching. In L. Milroy \& P. Muysken (arg.), One Speaker, Two Languages, Cross-disciplinary Perspectives (233-256 or.). Cambridge: Cambridge University Press.

Pérez Gaztelu, E. \& Zulaika Ijurko, E. (2012). Idatziz komunikatu. Gazteak eskolan idazten. Donostia: Deustuko Unibertsitatea.

Pérez Gaztelu, E. \& Zulaika Ijurko, E. (2014a). Comunicarse escriblando en las redes. Revista de la Asociación Española de Investigación de la Comunicación (RAEIC), 1, 117-128.

Pérez Gaztelu, E. \& Zulaika Ijurko, E. (2014b). Gzteak lgnrtn idztn: Mintzidatzien antolamendua. I. Aduriz \& R. Urizar (arg.), Euskal hizkuntzalaritzaren egungo zenbait ikerlerro. Hizkuntzalari euskaldunen I. topaketa (111133. or.). Bilbo: Udako Euskal Unibertsitatea.

Pérez Gaztelu, E. \& Zulaika Ijurko, E. (2016a). Adierazgarritasun zantzuak euskal gazteen txatetan ;). Gogoa, 14, 105-130.

Pérez Gaztelu, E. \& Zulaika Ijurko, E. (2016b). Estrategias comunicativas en las conversaciones «escribladas» de chat. El contacto lingüístico. In J. A. Achón, L. Arrieta \& J. M. Imízcoz (arg.), Antes y después de los mass media. Actores y estrategias comunicativas (358-376. or.). Madril: Dyckinson.

Poplack, S. (1980). Sometimes I'll start a sentence in spanish y termino en español: towards a typology of code-switching. Linguistics, 18(7/8), 581-618.

Redouane, R. (2005). Linguistic Constraints on Codeswitching and Codemixing of Bilingual Moroccan Arabic-French Speakers in Canada. In J. Cohen, T. Kara, K. McAlister, K. Rolstad \& J. MacSwan (arg.), ISB4: Proceedings of the 4th International Symposium on Bilingualism (1921-1933. or.). Somerville, MA: Cascadilla Press.

Rotaetxe, K. (1988). Sociolingüística. Madril: Síntesis.

Rotaetxe, K. (1999). Alternancia de código: uso y restricciones tipológicas. Fontes Linguae Vasconum, 80, 59-72. 
Sebba, M. (2012). Researching and Theorising Multilingual Texts. In M. Sebba, S. Mahootian \& C. Jonsson (arg.), Language Mixing and Code-Switching in Writing: Approaches to Mixed-Language Written Discourse (1-26. or.). Abingdon, UK: Routledge.

Wei, L. (1998). The 'why' and 'how' questions inteh analysis of conversational code-switching. In P. Auer (arg.), Code-Switching in conversation. Language, interaction and identity (156-176. or.). Londres: Routledge.

Zentella, A. C. (1997). Growing up bilingual. Puerto Rican children in New York. Blackwell: Oxford. 